\title{
La imagen turística del campo pampeano bonaerense (Argentina) desde la promoción oficial
}

\section{Cecilia Pérez Winter}

Instituto de Geografía, Universidad de Buenos Aires, Buenos Aires, Argentina

Instituto de Ciencias Antropológicas, Universidad de Buenos Aires, Buenos Aires, Argentina

ORCID iD: 0000-0002-2880-5834

Correo electrónico: cecipw@gmail.com

\section{Claudia Troncoso}

Instituto de Geografía, Universidad de Buenos Aires, Buenos Aires, Argentina ORCID iD: 0000-0002-1390-2594

Correo electrónico: claudia.a.troncoso@gmail.com
Recibido

octubre de 2018

Aceptado

marzo de 2019

doi: $10.34096 /$ cas.i50.5341

\section{Resumen}

En este artículo proponemos indagar las estrategias de promoción turística que se implementaron desde la Secretaría de Turismo de la provincia de Buenos Aires entre 20102015. Para ello, examinamos las imágenes fotográficas incluidas en la folletería - junto con los textos que la acompañan-, como parte de la estrategia de construcción de una provincia diversa, rural y turística. Para el análisis fueron considerados la cantidad y tamaño de las fotografías presentes en los folletos, su composición, resolución y otros aspectos técnicos en la construcción de la imagen, y se examinó también el contenido discursivo. Así, concluimos que las imágenes fotográficas van ganando relevancia en los folletos analizados, a la vez que adquieren diferentes funciones (ilustrar, singularizar, etc.). Asimismo, las imágenes textuales y visuales configuran una ruralidad bonaerense idealizada, a partir de "clichés" y reproducción de "mitos" que dan protagonismo a la figura del gaucho, a las estancias y a ciertos pueblos rurales.

\section{The tourist image of the pampas countryside (Argentina) through official promotion}

\author{
Abstract \\ This article examines tourism promotion strategies implemented by the Buenos Aires \\ province Secretariat of Tourism between the years 2010-2015. We analyze the pho- \\ tographic images -and their descriptions- included in official brochures as part of a \\ strategy to create a diverse, rural and touristic province. For the analysis of brochures \\ we considered, on the one hand, the quantity and size of photographs, in addition \\ to their composition, resolution and other technical aspects in the construction of \\ the image. On the other hand, the discursive content of brochures. We conclude that
}

\section{Palabras clave}

Turismo rural; Lugar turístico; Imagen fotográfica; Imagen turística; provincia de Buenos Aires

\section{Key words}

Rural tourism; Tourist place; Photographic image; Tourist image; province of Buenos Aires 
photographic images are gaining relevance in the analyzed brochures, while acquiring different functions (to illustrate, singularize, etc.). Likewise, textual and visual images create an idealized rurality of the province of Buenos Aires, based on "clichés" and the reproduction of "myths" that grant relevance to the figure of the gaucho, estancias and certain rural towns.

\section{A imagem turística da pampa bonaerense (Argentina) através da promoção oficial}

\section{Resumo}

Palavras-chave

Turismo rural; Lugar turístico; Imagem fotográfica; Imagem turística; província de Buenos
Neste artigo indagamos as estratégias de promoção turística que foram utilizadas pela Secretaria de Turismo da província de Buenos Aires entre 2010 e 2015. Para esse fim analisamos as imagens fotográficas incluídas nos folhetos -junto aos textos que as acompanham- como parte da estratégia de construção de uma província diversa, rural e turística. $\mathrm{Na}$ analises considerou-se a quantidade e o tamanho das fotografias presentes nos folhetos, sua composição, resolução e outros elementos técnicos na construção da imagem, examinando também o conteúdo discursivo. Concluímos que as imagens fotográficas vão ganhando importância nos folhetos analisados e adquirem diferentes funções (ilustram, singularizam, etc.). Ainda, as imagens visuais e textuais configuram uma ruralidade bonaerense a partir de "clichês" e a reprodução de "mitos" que dão protagonismo à figura do gaucho, às estâncias e a certos povoados rurais.

\section{Introducción}

Entendemos que el turismo es una práctica socioeconómica asociada al ocio que involucra la transformación (material y simbólica) de lugares a partir de una serie de acciones concretas efectuadas por diversos actores vinculados - directa o indirectamente - con esta actividad (Britton, 1991; Bertoncello, 2002). Dentro de este proceso, nos interesa focalizar en cómo se construyen las imágenes turísticas. En ellas, el material visual tiene gran relevancia, ya que orienta la forma de ver/consumir los lugares (Hughes, 1992).

El análisis de estas imágenes-y su papel en la definición de atractivos-y, en última instancia, en la conformación de destinos turísticos, ha sido abordado desde el ámbito académico. Lejos del tratamiento instrumental vinculado al marketing turístico que prevalece en el mundo del turismo (McCabe, 2014), desde las ciencias sociales se ha intentado comprender el papel que ciertas ideas e imágenes juegan como aspectos centrales de la dimensión simbólica implicada en todo proceso de invención de lugares turísticos (Knafou, 1991; Dann, 1996; Selwyn, 1996). Tempranamente, desde la antropología se ha tomado en cuenta el lugar de las imágenes para comprender el turismo. En The tourist. A new theory of the leisure class (1976), Dean MacCannell propuso que los viajes turísticos tienen por objeto la colección de un conjunto de imágenes de distinto tipo y origen. Con posterioridad, desde la sociología, John Urry, en The tourist gaze (1990), planteó el concepto de "mirada turística", con lo cual inauguró una línea de trabajo sobre los procesos por los cuales se generan y difunden imágenes e ideas acerca de lugares, creadas institucionalmente y compartidas socialmente. Este concepto rescata dimensiones históricas y socioculturales para definir las preferencias turísticas por determinados objetos, sociedades y espacios. El interés por 
comprender el turismo asociado a lugares particulares y comunidades locales ha generado contribuciones específicas también desde la antropología y la geografía. ${ }^{1}$ Algunos aportes provenientes de las ciencias sociales han puesto el énfasis en aspectos vinculados con la generación, difusión, consumo, reproducción y cuestionamiento de imágenes turísticas. Entre ellos, los que asocian turismo e imaginarios (Hiernaux, 2002; Adams, 2004; Gravari-Barbas y Graburn, 2012; Salazar y Graburn, 2014); aquellos que analizan imágenes relacionadas con la práctica turística, como fotografías (Crawshaw y Urry, 1997; Bracco, 2017), postales (Markwick, 2001; Lois y Troncoso, 2017), folletería (Scarles, 2004), cartografía (Del Casino y Hanna, 2000); los que abordan las imágenes turísticas como parte de la cultura visual contemporánea (Crouch y Lübbren, 2003; Palmer, 2009; Aquino, 2016); y otros que indagan las imágenes que generan ciertos actores vinculados específicamente a la promoción oficial (Morgan y Pritchard, 1998). En este marco, consideramos que las fotografías son un recurso significativo útil para definir los atractivos y difundir los destinos turísticos. Estas son objetos - independientemente de su soporte- que, como tales, se construyen social e históricamente, se utilizan, consumen, distribuyen y descartan. A su vez, reflejan un fragmento de algo que se busca visualizar, mediante la implementación de elementos técnicos y estéticos que generan una respuesta en quien las observa (Edwards y Hart, 2004).

En el caso del turismo, las fotografías - y el texto que las acompaña en los folletos, páginas web, mapas y redes sociales-, por una parte, colaboran en conformar una imagen turística recuperando imaginarios y fantasías existentes de ciertas geografías y "otros" culturales; creando y comunicando ciertos atributos, características y valores asociados al lugar turístico (Barthes, 1999; Hall, 2003; Salazar y Graburn, 2014). Por otra parte, la fotografía es un elemento esencial que en muchas ocasiones constituye y le da propósito al turista y la realización del viaje (Chalfen, 1979). En definitiva, la construcción y uso de las imágenes fotográficas inciden en la experiencia turística y en la conformación de nuevas geografías asociadas al turismo (Larsen, 2006). Por todo ello es que nos interesa tomar la imagen fotográfica como fuente de análisis, que, al igual que el texto, nos permite indagar - y contrastar- un amplio conjunto de aspectos: qué tipo de versiones identitarias se configuran, qué tipo de relaciones de poder se establecen y legitiman; y qué sujetos y elementos se seleccionan para construir un destino, entre otros.

Ante lo expuesto, nos proponemos indagar cómo la imagen fotográfica construida desde la Secretaría de Turismo de la Provincia de Buenos Aires (Argentina) participa en la definición de la provincia como lugar turístico. ${ }^{2} \mathrm{El}$ interés por abordar estos aspectos se vincula con los procesos que desde las décadas de 1970-1990 tuvieron lugar en las áreas rurales de la provincia que involucraron una serie de transformaciones socioeconómicas y simbólicas que incluyeron la creciente proliferación del turismo como actividad no agraria (Castro y Zusman, 2016). Así, la provincia de Buenos Aires, cuyo desarrollo turístico históricamente explotó de manera predominante las áreas costeras (Pastoriza, 2011), no es una excepción al proceso global de mercantilización turística del "campo" (Aguilar Criado, Merino Baena y Migens Fernández, 2003). En este marco, nos preguntamos: ¿a qué imaginarios geográficos y sociales se apela para construir el lugar turístico rural?, ¿qué papel juega la imagen fotográfica en las formas de presentar destinos turísticos en ámbitos rurales?, ¿qué elementos, prácticas y sujetos se seleccionan para incluir dentro de la idea de ruralidad turística local/nacional?, ¿qué actores intervienen en esa construcción?

Los objetivos del artículo son identificar y analizar: (i) cuáles han sido las estrategias de promoción turística implementadas por la Secretaría de Turismo para orientar dicha actividad hacia el interior de la provincia, particularmente, aquellos que exaltan los ámbitos rurales. Y, como parte de ese proceso, (ii) qué papel han tenido los materiales de promoción elaborados por esta dependencia (especialmente la folletería turística)
1. Para una presentación general de las formas en que desde la antropología se ha abordado el turismo, véase la obra ya citada de MacCannell (1976), Smith (1989) y Pereiro y Fernandes (2018). Para el caso de la geografía, pueden consultarse Hiernaux (2006), Wilson (2011) y Williams y Lew (2015).

2. Este artículo es producto de la investigación realizada en el marco del Programa de Postdoctorado de la Facultad de Filosofía y Letras (UBA) por parte de la primera autora. 
para configurar y promover los nuevos atractivos/destinos del interior de la provincia de Buenos Aires. En particular, nos interesa examinar qué localidades, elementos, sujetos y prácticas fueron seleccionadas para representar el campo pampeano-bonaerense. Para ello, analizamos los folletos turísticos oficiales - poniendo énfasis en las imágenes fotográficas, pero también en los textos que las acompañan - elaborados y difundidos por la Secretaría de Turismo bonaerense entre 2010 y 2015. Es en ese periodo que dicha actividad comienza a consolidarse en los espacios rurales de la provincia a partir del fortalecimiento del programa "Pueblos Turísticos" y de la creación de la región turística "Campos" (Pérez Winter, 2014). Todos los folletos analizados fueron acopiados en sus lugares de distribución, a partir de nuestra participación en las ferias dedicadas a esta temática (Feria Internacional de Turismo, Feria de Turismo Provincia de Buenos Aires) o mediante la consulta en la Casa Provincial (de la ciudad de Buenos Aires), en la Secretaría de Turismo (ciudad de La Plata) y en las direcciones de Turismo de los municipios donde realizamos trabajos de campo (San Andrés de Giles, San Antonio de Areco, Exaltación de la Cruz y Cañuelas).

Para el estudio de las imágenes fotográficas de los folletos se tuvieron en cuenta los aspectos: (i) composicionales: la organización espacial, contenido, paleta de colores; (ii) técnicos: profundidad del campo visual, luz e iluminación, contraste, encuadre, ángulo de la toma, punto focal, lugar de la toma (aire libre o en interiores); y (iii) social: es decir, las relaciones sociales, económicas, políticas sobre las que imagen y texto ofrecen pistas para su interpretación (Rose, 2002). Asimismo, se realizó un análisis semántico en el que se identificaron el género - retrato, paisaje- y la temática - actividad recreativa, gastronomías, fiestas, etc.- - Desde lo semiótico, se identificó y examinó qué signos y símbolos son utilizados como representativos, en este caso, de la ruralidad bonaerense (Barthes, 1986; Rose, 2002; Santillán, 2010). En cuanto a los textos de los folletos, se realizó un análisis cualitativo, a partir de indagar el lenguaje promocional turístico, para detectar tanto "clichés" (Dann, 2001), como otras ideas que los contradicen, que construyen -material y simbólicamente- la ruralidad turística bonaerense.

El artículo se encuentra estructurado de la siguiente manera: primero se expone, a modo de contextualización, una reseña sobre el desarrollo turístico hacia el interior de la provincia de Buenos Aires y las estrategias de promoción adoptadas. Posteriormente, se presentan y discuten los resultados del análisis realizado. Por último, exponemos las reflexiones finales.

\section{El desarrollo turístico hacia el interior de la provincia de Buenos Aires}

La provincia de Buenos Aires tiene una extensión de alrededor de 308.000 km2; viven en ella 15.625.084 habitantes, según el Censo Nacional de Población Hogares y Vivienda de 2010, lo que la convierte en una de las jurisdicciones de la Argentina con mayor densidad demográfica. Está compuesta por 135 municipios, y la ciudad de La Plata se configura como capital provincial. Se extiende en parte de la llanura pampeana, área histórica de producción agrícola y ganadera que también ha albergado otras actividades económicas como la industria y la minería, a las que se suma el turismo, concentrado desde sus inicios en la costa atlántica (Quesada y Cadelli, 2012).

En efecto, algunos balnearios bonaerenses, entre los que se destaca Mar del Plata, ya eran frecuentados por las élites argentinas asentadas en la ciudad de Buenos Aires desde fines del siglo xIx. También lo era la localidad de Tigre, asociada a la recreación y el deporte. Conforme avanzó el siglo xx, nuevas áreas del interior se sumaron al mapa turístico provincial, entre ellas, las zonas serranas de la provincia. Asimismo, a este panorama turístico bonaerense se unieron progresivamente Luján y San Antonio de Areco (Bertoncello, 2006; Pastoriza, 2011; Bertoncello e Iuso, 2016). En el primer caso, 
por ser un lugar de peregrinación, y en el segundo, por el vínculo que se construyó entre la localidad y la activación de una versión de tradición regional (Pérez Winter, 2016). El área atlántica y las sierras siempre han tenido un lugar privilegiado dentro de la promoción turística provincial para las estaciones estival e invernal, respectivamente (Pastoriza, 2011).

Cabe señalar que, a escala nacional, en décadas recientes, la Argentina experimentó un crecimiento en el turismo, especialmente durante la década de 2000. Este se manifestó, entre otras cosas, en las cifras de llegadas de turistas internacionales y en el movimiento de aquellos locales en el interior del país (Ministerio de Turismo, 2015). En este marco, el turismo denominado rural emergió durante la décadas 1980-90, y se consolidó poscrisis nacional (2001) como una alternativa que permitiría diversificar las actividades económicas de las áreas rurales del país (Ratier, Ringuelet y Soncini, 2013; Castro y Zusman, 2016).

La provincia de Buenos Aires fue unas de las beneficiadas por los programas nacionales que comenzaron a orientar aquel tipo de modalidad. Algunas experiencias fueron promovidas por el Instituto Nacional de Tecnología Agropecuaria (INTA) (Guastavino, Rozemblum y Trímboli, 2009). Otro ejemplo fue el programa "Raíces" (2000) implementado por la - en aquel momento- Secretaría de Agricultura, Ganadería, Pesca y Alimentos, en coordinación con la Secretaría de Turismo de Nación. Entre las localidades bonaerenses que participaron se encontraban Pipinas (municipio Punta Indio), La Niña (o Aurora) y 9 de Julio (del municipio homónimo), y Azcuénaga (municipio San Andrés de Giles).

Hasta la década de 1990-2000, existían varias localidades del interior de la provincia que no eran contempladas dentro de la agenda turística del estado bonaerense. No obstante, en concordancia con el contexto nacional recién mencionado, en la provincia se comenzó a diseñar sus propias estrategias de desarrollo turístico hacia el interior de su territorio, incluyendo la valorización de los ámbitos rurales (Schlüter, 2003; Pérez Winter, 2014). Así, se comenzaron a ensayar las primeras tentativas desde la en ese momento denominada Subsecretaría de Turismo y Desarrollo Regional, con la creación de la marca "Viva las Pampas" (2002) y submarcas como "Viva el Aire", "Viva la Tradición", "Viva el Polo". Estas permitían configurar diferentes "productos turísticos". Ello fue acompañado por el diseño de una página web oficial que posibilitaba a los municipios incluir información relevante sobre servicios y puntos de interés sobre cada uno, además de la elaboración del Plan Estratégico para el Desarrollo Turístico de la Provincia de Buenos Aires (2000-2003). La relevancia otorgada a la promoción turística se expresó en un evento denominado Feria de Turismo de la Provincia de Buenos Aires (FEBATUR, 2003).

Estas primeras iniciativas fueron continuadas y consolidadas por el gobierno de Daniel Scioli (2007-2015), quien había ocupado el cargo de secretario de Turismo y Deporte de la Nación entre 2001-2003. En 2008 se creó la Secretaría de Turismo, con nuevos programas, direcciones y presupuesto propio (Decreto $N^{\circ} 3.977$, 2008). En 2010, se promulgó la Ley Provincial de Turismo $\mathrm{N}^{\circ} 14.209$ de 2010, que reemplaza a la Ley $\mathrm{N}^{\circ}$ 5.254 de 1948 y presenta artículos similares a los que habían sido planteados por la Secretaría de Turismo de Nación bajo la Ley Nacional de Turismo 25.997 de 2005. Con ella se anunció la creación del Consejo de Promoción Turística. Asimismo, se divulgó el Plan Anfitrión 2021, el cual promueve una gestión participativa con los municipios. Y en el año 2014 se crearon los polos de desarrollo turístico con el propósito de facilitar la creación de "productos turísticos", desde una gestión más participativa, descentralizadora e integradora entre el área de turismo provincial y las municipales (Decreto provincial $\left.\mathrm{N}^{\circ} 13,2014\right)$. 
3. En diciembre de 2015 finalizó la gestión del gobernador de la provincia de Buenos Aires Daniel Scioli (Frente para la Victoria) y fue sucedido por María Eugenia Vidal (coalición Cambiemos), quien al poco tiempo de asumir impulsó algunos cambios en la gestión turística de la provincia.
El interés en desarrollar esta actividad hacia el interior de la provincia fue acompañado por la implementación de otras acciones que buscaron promocionar expresiones y lugares asociados a la ruralidad, como los pueblos, celebraciones locales, saberes sobre los "usos y costumbres" del campo, etcétera. Así, podemos mencionar las siguientes propuestas: el Programa Pueblos Turísticos; el registro de estancias y celebraciones populares; la regionalización turística y las rutas gastronómicas e histórico-culturales (Pérez Winter, 2017). Estas propuestas fueron visibilizadas mediante campañas de promoción, como la denominada "Viví la diversidad", promovida durante el año 2008, o la gira nacional realizada entre los meses de noviembre y diciembre del año 2013. El propósito era difundir no solo las costas, sino también otros potenciales destinos identificados como regiones (delta, campo, entre otras). Esto diversificó la oferta según las distintas épocas del año (para el verano las áreas costeras bonaerenses y para el resto del año el interior). De hecho, para organizarla se elaboró el Programa de Creación del Calendario Turístico Anual como herramienta de ordenamiento y de promoción de eventos de carácter local/provincial, además del Programa de Asistencia Técnica en Promoción a Municipios y Zonas Turísticas. Asimismo, la modalidad de turismo rural se colocó como una de las propuestas incluidas en el Plan de Regionalización de Desarrollo para la provincia 2010-2020 (Provincia de Buenos Aires, 2011).

\section{La promoción turística de la región "campo"}

Las iniciativas recién señaladas buscaron configurar el ámbito rural de la provincia como atractivo/destino turístico. En primer lugar, nos interesa mencionar la creación de la regionalización turística durante el periodo 2010-2015. Existieron divisiones previas, como las de 1981 (Decreto No 1034/81), 1990 y 1994, en las que el criterio de zonificación era la selección de atributos paisajísticos o topográficos: costa o litoral, serrana, metropolitana; y a las áreas que no presentaban un flujo turístico significativo se las denominaba según su orientación cardinal: norte, sur (Mantero, 2001; Benseny, 2002). No obstante, la relevancia que fue adquiriendo el turismo en la agenda del estado bonaerense llevó a que, desde al menos el año 2010, se diferenciaran cinco regiones turísticas (Mongan, Lombardi y Salim, 2012), categorización que se mantuvo vigente hasta mediados de 2018. ${ }^{3}$ En estas regiones (Campos, Playas, Delta, Ciudades, Sierras y Ríos y Lagunas) participaban la mayoría de los municipios que integran el territorio provincial (Pérez Winter, 2014).

Para los propósitos de este artículo, nos interesa indagar en la región turística "Campos". Es en torno a ella que desde el estado provincial se puso el acento en los aspectos rurales del espacio turístico bonaerense. Dicha región estaba conformada por 23 municipios, localizados en las áreas de mayor producción agropecuaria de la provincia (ganadera y de oleaginosas) (Quesada y Cadelli, 2012): Bolívar, Bragado, Brandsen, Cañuelas, Capitán Sarmiento, Carmen de Areco, Castelli, Chacabuco, Chascomús, Exaltación de la Cruz, General Lavalle, General Madariaga, Lobos, Luján, Magdalena, Mercedes, San Miguel del Monte, Pergamino, General Paz, Saavedra, San Andrés de Giles, San Antonio de Areco y Tapalqué.

En esta región se proponía: "vivir una tradición rural centenaria y peculiar en pleno siglo Xxi [...] [con]... pueblos rurales [...] que narran parte de la historia argentina, estancias que reseñan un pasado y un presente agrícola-ganadero" (Pérez Winter, 2015, p. 363). Este texto, que se encontraba en la página oficial, estaba ilustrado por una serie de imágenes fotográficas que suponían representar las particularidades de cada localidad (Pérez Winter, 2015). Cada región turística era acompañada de folletería oficial durante el periodo 2010-2015. En ella podemos observar algunos cambios y persistencias en cuanto a la cantidad y tipo de imágenes fotográficas utilizadas y las descripciones presentadas para construir la región turística "Campo". 
Para empezar, los primeros dos folletos, que denominamos "genéricos", diseñados entre el 2011 y 2012, introducen todas las regiones, modalidades y experiencias que caracterizarían al turismo en la provincia de Buenos Aires en 14 planos desplegables, ilustrados con 33 fotografías cada uno de ellos. Cada plano incluye un breve texto descriptivo acompañado de una foto, y cada folleto incluye un mapa de rutas de la provincia de Buenos Aires. En general, se exhiben escenas a cielo abierto con días soleados, y en algunas ocasiones con turistas y comunidades locales realizando alguna actividad. Las fotografías son de tamaño pequeño $(5 \times 3 \mathrm{~cm})$, no tienen buena resolución y tampoco presentan epígrafe que permita identificar el lugar de la toma o quién fue el autor de la fotografía (fotógrafo profesional, agencia de publicidad, banco de imágenes de provincia/municipio, etc.). Por lo tanto, es difícil apreciar detalles en ellas.

Los dos folletos genéricos presentan a la provincia como "tierra de gauchos, corazón de las pampas", y enfatizan que en ella se: "narra parte de la historia argentina"; en la que se "conjugan armoniosamente hermosas playas, con cientos de pueblos y grandes estancias". Asimismo, describen a la provincia como un ámbito productivo donde se articula el "pasado y presente agrícola ganadero" con una "llanura famosa por su riqueza natural", lo cual destaca la fertilidad de sus suelos para cultivo. No obstante, también buscan mostrar una provincia diversa y de contrastes. Para ello se recurre a una estrategia de composición en la que se presentan, en cada página del folleto, dos regiones contrapuestas, como "Las Playas" y "El Campo", acompañadas por fotografías que ilustran y muestran ese contraste (Figura 1).

En ambos folletos genéricos, la región Campo recupera y fortalece las ideas asociadas a la ruralidad a partir de la singularidad de la "vida gauchesca": las estancias, los cultivos, el ganado. Se reitera el carácter fértil de las tierras destacando que su "riqueza" es producto del "trabajo de nuestra gente", con lo que se apela a una "comunidad imaginada" (Anderson, 1993) bonaerense, que luego detallaremos a quiénes incluye. El texto invita al turista a encontrarse con "paisajes de ensoñación" en un "reencuentro del hombre consigo mismo" y a "sentirse gaucho por un momento", mediante la visita a estancias históricas. Esto ya nos anticipa a uno de los sujetos que conforma esa "comunidad imaginada" bonaerense: el gaucho. Así, mediante esta figura masculina del gaucho, la Subsecretaría busca que cualquier turista se identifique con este arquetipo nacional y con el ámbito rural. La fotografía que acompaña este texto muestra a quien se define como un "gaucho". Aquel vestido con ropas tradicionales, como la boina típica de la región y pañuelo al cuello, que demuestra una actitud valiente al exponerlo en plena acción, atravesando enérgicamente un río o laguna con su tropilla (Figura 1). Una imagen que apela a la libertad y fuerza del hombre con sus caballos recorriendo el ámbito rural, como hacían antes los reseros. Esa misma imagen es recuperada en el folleto "Tierra de Gauchos", donde ocupa una cara entera. Así, mientras que para la región

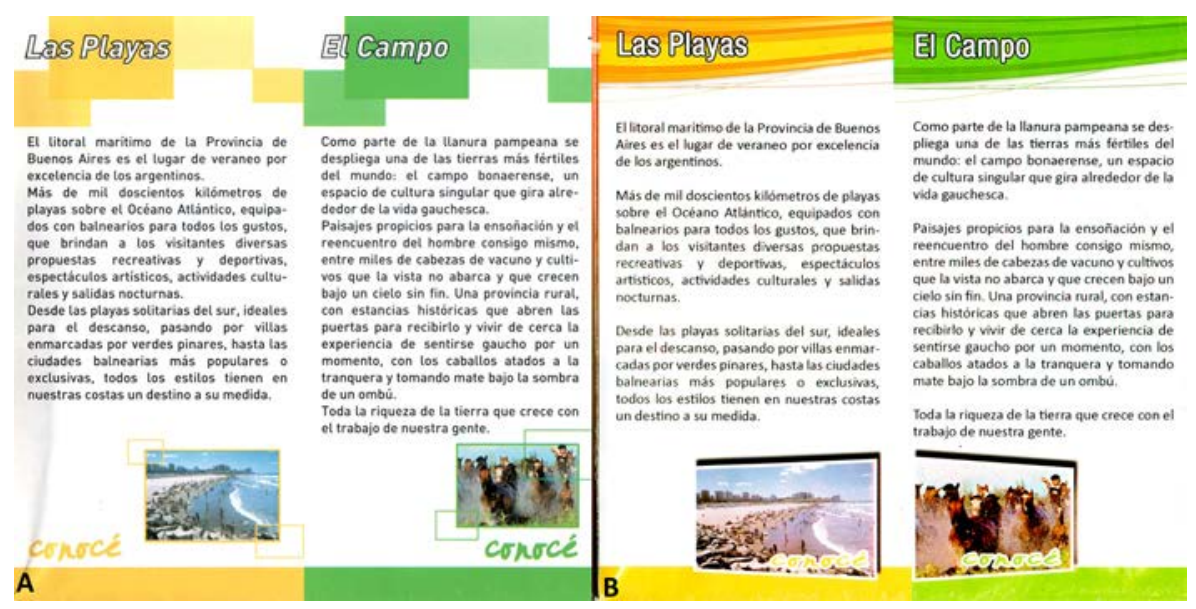

4. Cabe señalar que en 1939 , en la provincia de Buenos Aires se creó el Día de la Tradición -que en 1948 fue reconocido a nivel nacionalen el cual se activa la figura del gaucho como arquetipo nacional.
Figura 1. Folletos genéricos $A$. 2011, B. 2012, regiones turísticas: "Las Playas" y "El Campo". Fuente: Secretaría de Turismo Provincia de Buenos Aires. 
"Playas" se seleccionó una imagen que muestra a los turistas disfrutando del balneario, en "Campo" el protagonista es el "gaucho" con el cual el turista debería identificarse.

Entre los años 2012 y 2014, la Secretaría de Turismo bonaerense lanzó folletos individuales de cada región turística. Aquí nos interesa focalizar en los referidos a la región "Campo". El primero se había denominado "Tierra de Gauchos", y el segundo, directamente, "Campo". Ambos mantienen el mismo texto, sin embargo, las imágenes fotográficas muestran algunos cambios. Se repiten varias fotos, aunque también se presentan otras con diferente ángulo de toma de los mismos lugares o muestran otros ámbitos de las localidades que se incluyen en esa región. Una de ellas, que ocupa una cara entera del folleto "Campo", corresponde a una fotografía utilizada por la Estancia La Bamba (San Antonio de Areco) en su página de promoción turística. También se exponen imágenes de mayor calidad y, aunque disminuyen en cantidad (entre 16 y 23 fotos respectivamente) con respecto a los folletos genéricos, adquieren mayor tamaño, en algunos casos ocupando caras enteras. De hecho, se intercala una cara mixta (texto y fotografía) con una cara cubierta enteramente por una foto. Si bien las imágenes comienzan a ganar protagonismo, persiste su anonimización.

En ambos folletos se construye y muestra la ruralidad turística de la provincia mediante la selección y descripción de ciertos elementos organizados en torno a títulos como: "Los Pueblos", "El paisaje Pampeano", "Las Estancias", "Granjas", "Gastronomía”, "Actividades Gauchescas", "Artesanías". Se refuerza la idea de la provincia de Buenos Aires como "tierra de gauchos", donde se mantienen las tradiciones a partir del saber-hacer. Esto incluye la elaboración de artesanías de plata y cuero, que son "preservadas desde sus antepasados como símbolo de continuidad y valoración de esta expresión cultural" (Folleto "Campo" 2012- 2014); el poder realizar un asado con cuero, preparar un mate y otras comidas "típicas" (pastelitos, empanadas, pucheros) o poseer habilidades ecuestres; así como preservar las fiestas locales y la arquitectura pampeana de los pueblos y de las estancias. Ello en parte es posible - según la folletería - gracias a las comunidades locales, de las que se destacan sus raíces europeas, lo que abona a la idea del campo bonaerense como ámbito de inmigrantes laboriosos. Así, la "comunidad imaginada" bonaerense no solo incluye la figura del gaucho bajo su versión regional, sino también a una población "blanca y europea" trabajadora.

Un aspecto que se activa dentro de las versiones del pasado del campo bonaerense es su condición de ámbito de "frontera": es llamativo cómo se acepta y naturaliza la idea de que se "conquistó un desierto", con lo cual se legitima el proceso de expropiación de las tierras indígenas para conformar las estancias de las élites durante el siglo XIX como ámbitos civilizados.

Otro elemento que forma parte de la historia de estos ámbitos es la relevancia que tuvo la expansión del ferrocarril en su conformación y su dinámica productiva (aspecto que contrasta con la inactividad actual de estos servicios). Las estaciones de tren $-\mathrm{y}$ otras construcciones asociadas a la historia ferroviaria-, por una parte, rememoran una época dorada, de producción y dinamismo económico y social del campo. Por otra parte, muestran un presente de resignificación productiva al reciclar estas construcciones al servicio del turismo como centros de información, restaurants, alojamientos, centros culturales, museos, y colocan al turismo como parte del proceso revitalizador de las áreas rurales actuales.

Así como se recuperan versiones de pasados asociados a momentos de auge productivo del campo, también se ponen en valor características actuales - algunas de ellas, asociadas a las "nuevas ruralidades" - , como el amplio paisaje pampeano bonaerense con su flora y fauna, las granjas que muestran nuevas prácticas productivas y, mediante actividades educativas, se le permite al visitante "expresar su sensibilidad por la naturaleza y 


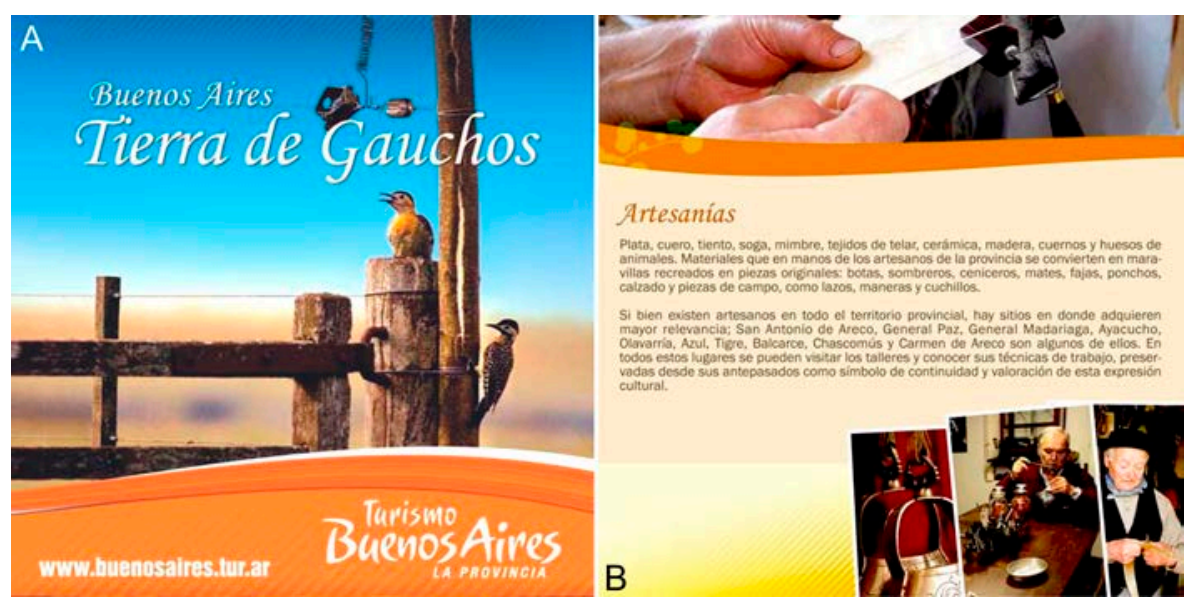

el medio ambiente en contacto con las distintas especies animales y vegetales" (Folleto "Campo" 2012- 2014).

Respecto de las fotografías, en ambos folletos ellas ilustran y refuerzan las ideas que se introducen en el texto. La mayoría son imágenes en exterior, y muestran un paisaje compuesto por elementos vinculados a la actividad agraria sin exhibir ciertas innovaciones tecnológicas que caracterizan los procesos de producción actual: mucho verde, arboledas, tranqueras, alambrados, corrales de palo a pique con animales, fardos de alfalfa, campos cultivados, molinos de agua. En otros casos, se muestran lugares de algún pueblo de la provincia con sus casonas históricas tipo chorizo, ladrillo visto, sus iglesias y estaciones ferroviarias, además de los almacenes de campo o pulperías de mediados del siglo xix y comienzos del xx. Asimismo, en el folleto "Tierra de Gaucho" predominan imágenes que colocan al campo vacío - como sinónimo de tranquilidad y seguridad- $y$, en menor medida, aquellas que muestran al "gaucho" realizando alguna actividad. De hecho, la foto de tapa muestra una tranquera, el alambrado con un ave posada, un pájaro carpintero al lado del poste y el paisaje difuso de fondo (Figura 2A). Esta imagen, junto con el título del folleto - “Tierra de Gaucho" - privilegiaría al paisaje pampeano-bonaerense como escenario del gaucho y no al él como sujeto/ atractivo principal. Aunque en el interior del folleto se exponen fotos con hombres vestidos con ropas tradicionales realizando alguna actividad vinculada con "lo gauchesco". Entre ellas, se destaca la artesanía sobre cuero y plata (Figura 2B); como señala Rotman, ese tipo de piezas tienen: "una connotación 'telúrica' que apela a 'lo nacional'; rememoran y atestiguan la esencia de un pasado glorioso, [...] y se reactualizan en la sociedad actual; se vinculan estrechamente con procesos identitarios a nivel de la nación" (2009-2010, p. 33).

En el folleto "Campo" observamos que el "gaucho" gana protagonismo al estar incluido en la imagen de tapa del folleto, acompañado por sus caballos en un corral de palo a pique (Figura $3 \mathrm{~A}$ ). En el interior se exhiben más fotos que, por una parte, exponen una recurrencia de la figura del gaucho. Por otra parte, muestran a las comunidades locales participando de alguna actividad cultural y/o recreativa - ahora también atractivo turístico, como la sortija o la taba, por ejemplo- o en interacción con el turista ofreciendo algún tipo de servicio, como espectáculos musicales o de danza, o cocinando el asado (Figura 3B).
Figura 2. A. Tapa del folleto "Tierra de Gauchos" (20122014). B. Artesanías tradicionales.

Fuente: folleto "Tierra de Gauchos" (2012-2014). 
Figura 3. A. Tapa del folleto "Campo" (2012-2014). B. Comunidad local ofreciendo servicio a Fos turistas Fuente: folleto “Campo" (20122014)
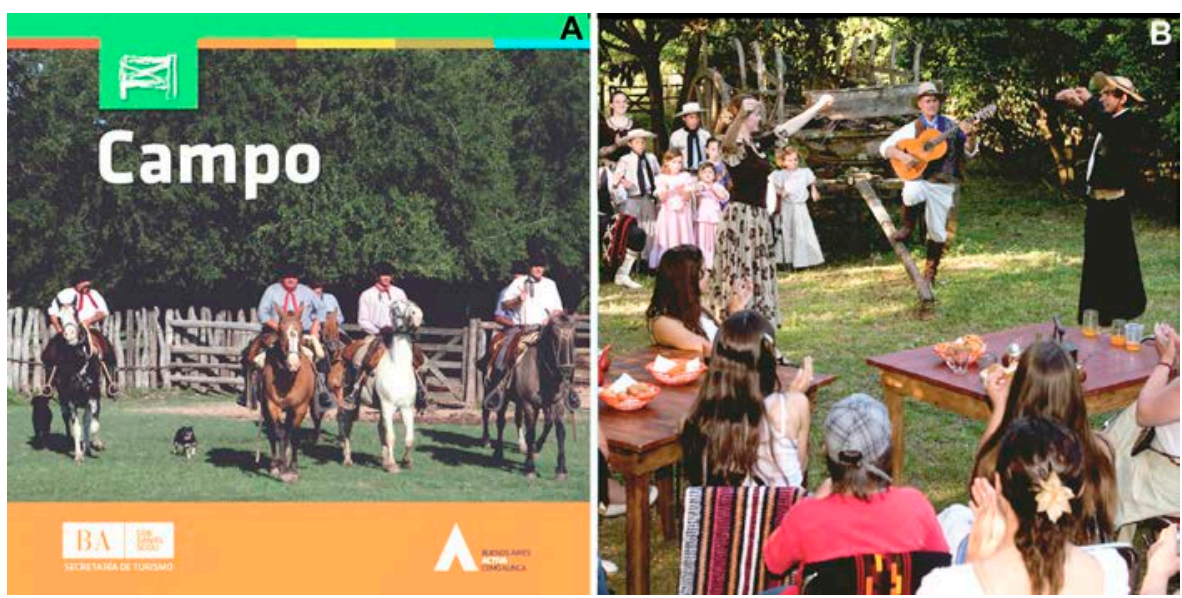

La promoción del programa "Pueblos Turísticos"

En el año 2008 se creó el Programa "Pueblos Turísticos", de modalidad comunitaria, con el propósito de que las propias comunidades de pequeños asentamientos (de hasta 2000 habitantes) se involucraran en el desarrollo turístico de sus lugares de residencia. Este programa busca dar continuidad a lo que se había establecido en la Ley $\mathrm{N}^{\circ} 13.251$ de 2004 de Promoción de Pequeñas Localidades Bonaerenses.

Si bien se consideran pueblos de las distintas regiones de la provincia de Buenos Aires (delta, sierras, etc.), el criterio de definición de "pueblo turístico" es el mismo que se utiliza para definir oficialmente en la Argentina a las aglomeraciones rurales: localidades de hasta 2000 habitantes. El programa busca promover: "el desarrollo de actividades y emprendimientos turísticos sostenibles en las pequeñas localidades de la Provincia de Buenos Aires, generando identidad, fuentes de empleo, recursos genuinos y favoreciendo el arraigo" (Secretaría de Turismo, 2008, p. 2).

Se fueron seleccionando asentamientos rurales que además: (i) manifiesten interés de la propia comunidad en participar; (ii) sean accesibles, es decir, se encuentren a menos de $200 \mathrm{~km}$ de centros urbanos de relevancia, como Buenos Aires, La Plata, Mar del Plata y Bahía Blanca, lo que propone una dirección costa-interior; (ii) estén relativamente preservados, en especial si poseen algún rasgo distintivo con el cual se pueda construir su singularidad turística (Velázquez Inoue, 2018).

Las primeras experiencias del programa se efectivizaron entre 2008-2009 con Villa Ruíz, Azcuénaga (San Andrés de Giles); Carlos Keen (Luján); Uribelarrea (Cañuelas); Gouin (Carmen de Areco); y Villa Logüercio (Lobos). Para 2015 alcanzó a incluir 24 pueblos, la mayoría de ellos conformados a fines del siglo xIX o comienzos del siglo xx, en el marco de la construcción del Estado-Nación argentino, que promovía la llegada de extranjeros para ocupar el territorio en expansión. Estas características son similares a las de los atractivos/destinos identificados en la región "Campo". Asimismo, en los pueblos seleccionados se destaca la antigüedad y la característica bucólica de pequeños asentamientos ligados a la vida rural tradicional, aunque en muchos de ellos se pueden encontrar nuevos y modernos elementos, como Internet y otros servicios mediante los cuales se procura generar una experiencia agradable y cómoda al visitante (además de ser de uso corriente por la población local).

Las ideas y propósitos presentados en el programa se reforzaron en la folletería emitida entre los años 2010 y 2015. En este caso, analizamos los 16 folletos que logramos reunir: cuatro elaborados durante 2010-2011, 2012, 2013 y 2015, y 12 que corresponden 
a localidades específicas pertenecientes al programa, elaborados en 2012. Estos fueron diseñados a medida que se iban incorporando nuevos poblados al programa.

Todos los folletos mencionados comparten la información básica: el propósito del programa, la ubicación de cada uno de los pueblos, los puntos de interés, servicios que se brindan y actividades que se pueden realizar. En todos ellos se ofrece una definición del turismo comunitario como: "aquel que fomenta el desarrollo de la actividad turística en pequeñas localidades no urbanas (sean rurales, litorales, serranas o insulares), que posean atractivos capaces de generar el desplazamiento de turistas o excursionistas hacia ese destino" (Folletería del programa Pueblos Turísticos, 2010-2015). Asimismo, se coloca como una certeza la capacidad del turismo de generar recursos para las localidades que se asumen como distintivas de esta modalidad turística cuando se afirma: "Una importante proporción de los beneficios quedará en la comunidad" (Folletería del programa Pueblos Turísticos, 2010-2015) y se resalta el patrimonio - con o sin reconocimiento formal- como un eje que distingue qué tipo de recursos turísticos se busca poner en destaque. Todo esto habla, no solo de los pueblos, sino del mismo programa, ya que, por una parte, esta garantía de desarrollo que se asume para el turismo comunitario justifica la creación y mantenimiento en el tiempo de ese proyecto. Por otra parte, la propia idea de que esta modalidad turística genera beneficios para la localidad funcionaría como atractivo, al menos para un visitante "comprometido", que busca colaborar con la comunidad de estos pueblos durante su visita.

Los dos primeros folletos - de 2010-2011 y de 2012, que incluían información sobre ocho y doce pueblos respectivamente-y la página web oficial del programa utilizaron, hasta mediados del año 2018, la misma foto de portada que también está presente en el interior de algunos de ellos. Ella exhibe un campo con fardos de alfalfa alineados; en el fondo se llega a ver una casa con silos, un molino (símbolo de Pueblos Turísticos) y una arboleda (Figura 4).

Sin embargo, estos impresos también presentan sus diferencias. Entre ellas, podemos señalar que el emitido entre 2010-2011 dedica más espacio a la descripción de cada localidad, detallando la cantidad de habitantes por pueblo, la posibilidad de disfrutar el entorno "natural", por ejemplo, con el avistaje de aves, caminatas o recorridos en bicicleta. Para cada pueblo se mencionan hechos históricos que tratan de otorgarle relevancia y singularidad. Por ejemplo, la referencia a las obras del ingeniero Francisco Salamone (1895-1959) declaradas patrimonio nacional (Decreto No 1138/2014).

Aunque las descripciones del folleto de 2012 son menos específicas que las del anterior, este se lanzó acompañado de otros, individuales, referidos a cada uno de los pueblos en particular, y presenta ocho caras desplegables. En ellos se amplía la información sobre los atractivos turísticos, con fotos - entre 10 y 16 , en su mayoría de $4,5 \times 3 \mathrm{~cm}-$ y su localización en un mapa (para mostrar la cercanía y accesibilidad). En algunos se explicita la relación - mediante la numeración correlativa - entre foto y atractivo identificado en el mapa. Asimismo, algunos de ellos van asociados con frases que remiten a las mismas ideas usadas en los folletos dedicados al "Campo" como "Historia, Naturaleza y Tranquilidad", "Historias de ayer, relatos de hoy", que dan cuenta de la

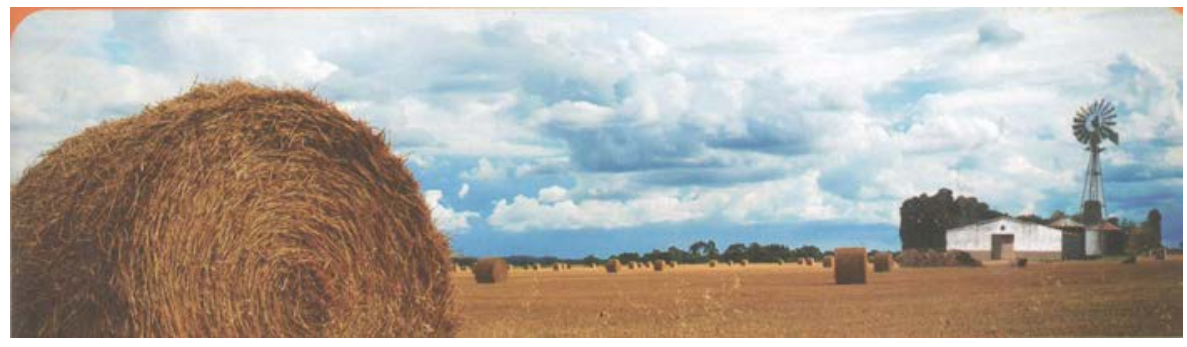

Figura 4. Imágenes de campo con fardos. Fuente: folletos "Pueblos Turísticos" correspondientes a los años 2010-2011 y 2012. 
Figura 5. Folletos "Pueblos Turísticos". A. 2010-2011; B. 2012 (general); C. 2013. llustraciones y textos de la localidad de Santa

Fuente: folletos "Pueblos Turísticos" (2010-2013)

Figura 6. Mix de imágenes que componen el interior del folleto. Fuente: folleto "Pueblos Turísticos" (2012).
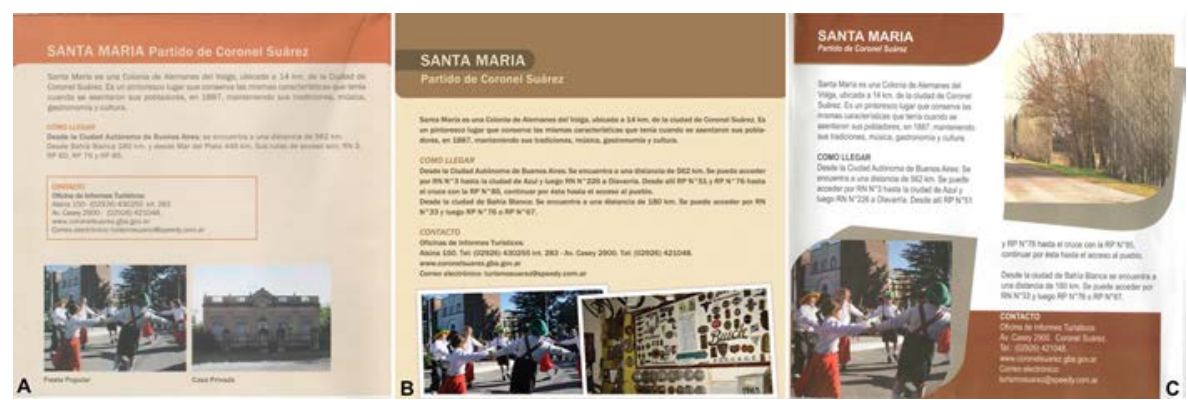

idea del pueblo como reservorio de identidad y el ámbito en el cual estar en "contacto con la naturaleza”. Por su parte, el que fue emitido en el 2013 presenta 16 pueblos del programa con algunas variaciones en el texto.

Si bien algunas fotografías fueron variando, los primeros tres folletos emitidos presentan dos imágenes para representar a cada pueblo turístico, además de la foto de tapa y otras que ilustran los textos sobre el programa (Figura 5 A, B y C). El del 2010-2011 presenta 20 fotos - con epígrafe (Figura 5A) que indica brevemente qué busca mostrar la foto (ej. "cementerio", "casa antigua", etc.) -, el de 2012, 43 fotos, mientras que el de 2013, 36 fotografías, en general con tamaños de $7 \times 7 \mathrm{~cm}$. Predominan las fotos de exteriores, de día, con tiempo despejado (soleados).

En algunos casos se observa el mismo paisaje/ámbito o lugar con diferente ángulo de toma, pero se mantiene el mismo propósito: reforzar el texto descriptivo e ilustrar las particularidades de cada pueblo al mostrar fotos de los espacios respecto de los cuales se supone que son los más emblemáticos: casonas antiguas, cascos de estancia, edificaciones para actividades productivas agropecuarias, pulperías y, sobre todo, aquellas que muestran la estación de ferrocarril. En la Figura 6 se puede observar un mix de imágenes que ocupan dos caras en el folleto del 2012 que sintetizan el tipo de selección realizada para los folletos de "Pueblos Turísticos".

Cabe señalar que en otros casos, el proceso de singularización es más explícito en el texto y en la imagen fotográfica. Así, en Santa María se hace referencia reiteradamente a la fiesta que celebra a la colectiva de inmigrantes del Volga (Figura 5), en tanto que para Saldungaray no deja de estar presente la obra que Salamone realizó en el cementerio de la localidad (Figura 7 A, B y C).

Todos los folletos de Pueblos Turísticos (2010-2015) presentan mapas donde se ubican estas localidades. Al contemplarlos sucesivamente, se puede observar cómo de
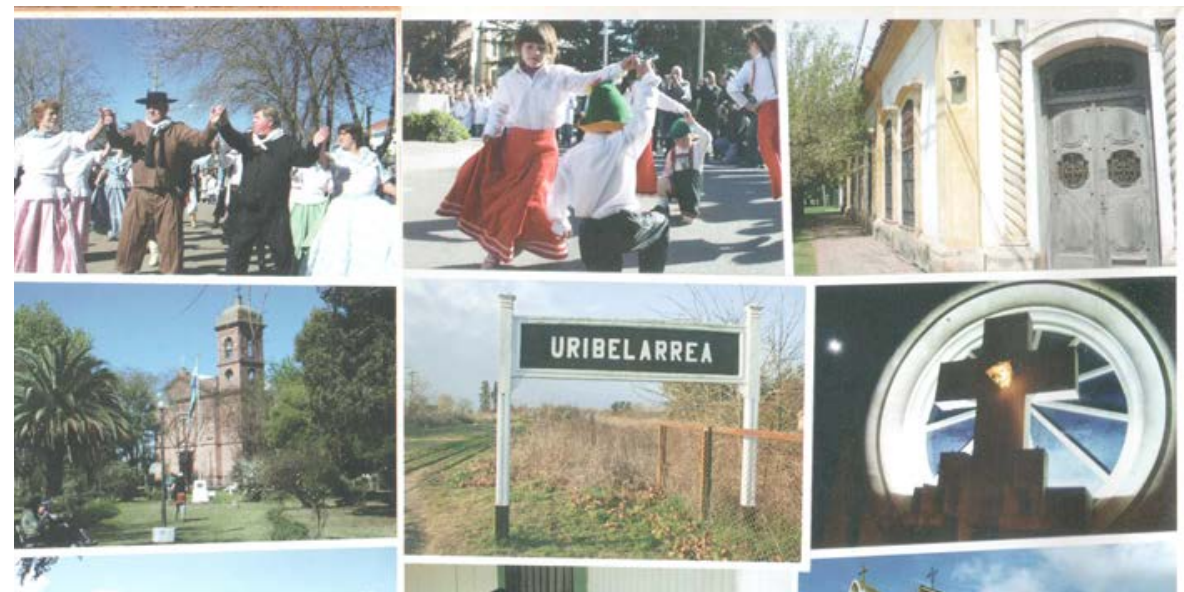


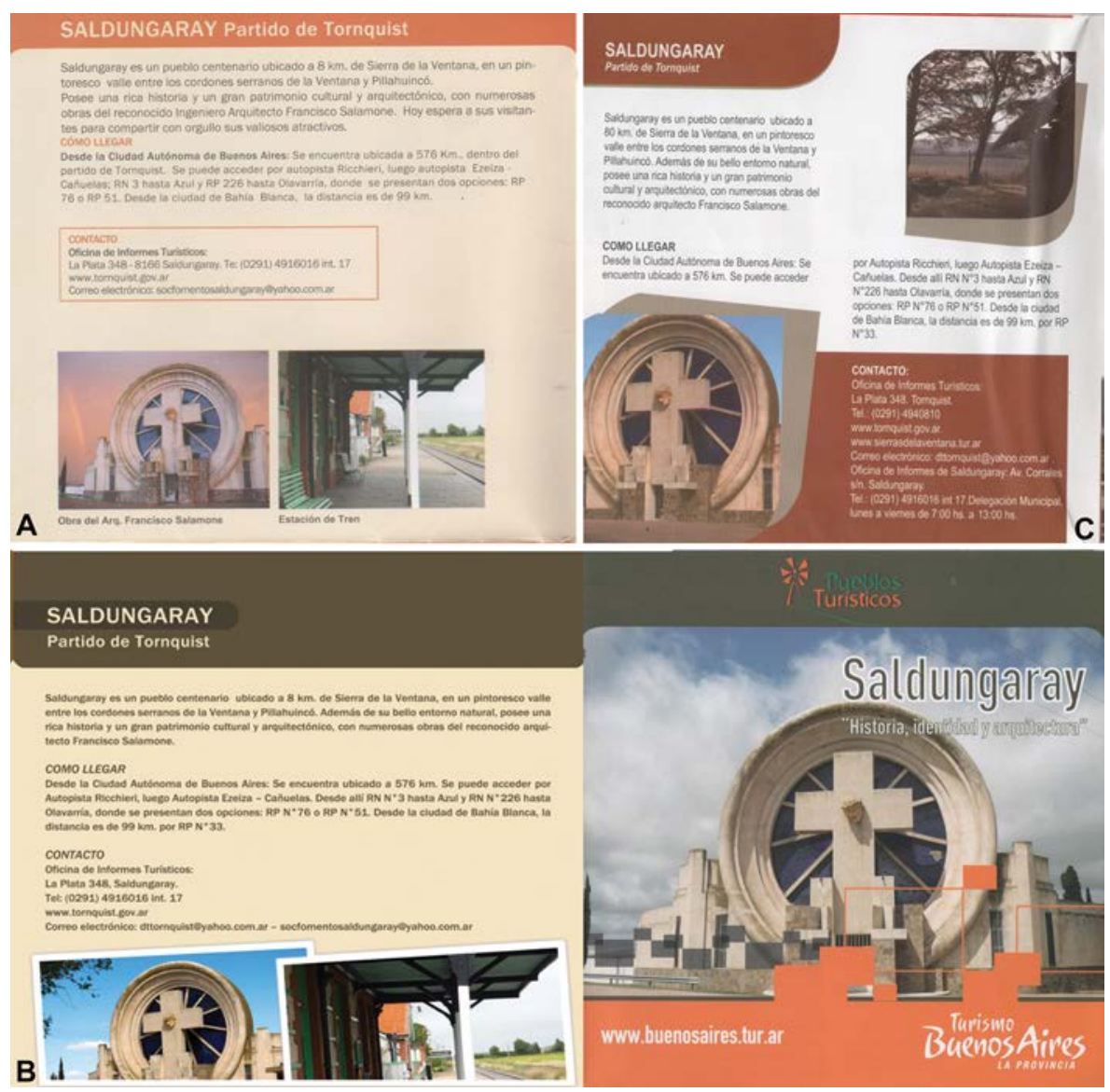

modo progresivo las áreas geográficas ocupadas por ellos se fueron ampliando. Es posible advertir que los pueblos seleccionados se definen por la cercanía de tres grandes núcleos urbanos: Buenos Aires-La Plata, Mar del Plata y Bahía Blanca. Esta cercanía es propicia para la visita de pocos días a estos lugares - tal como se destaca en los folletos denominados "Escapadas de fin de semana"-. Además, se hace evidente que se busca incorporar pueblos distribuidos equitativamente en el territorio provincial. Ello concuerda con la estrategia de la gestión provincial de lograr una mayor presencia del turismo al interior de la provincia. Asimismo, esta multiplicación de pueblos en la oferta del programa y la expansión territorial de esta modalidad parecen mostrar la consolidación de la iniciativa.

Finalmente, nos interesa detenernos en algunas particularidades del folleto diseñado en 2015. Por la cantidad de pueblos (24) incluidos en el programa y el tamaño de las imágenes, este folleto adquiere formato de cartilla. En él se presentan 39 fotos de $7 \times$ $14,5 \mathrm{~cm}$. Si bien se expone una foto por localidad, ella ocupa la mitad de la cara (Figura 8), y también se muestran otras ilustrativas de cara entera. Cabe señalar que vuelve a aparecer una imagen de un campo con fardos alineados muy similar a la que presentamos en la Figura 4, ya no como foto de tapa sino en el interior de la cartilla. Aunque es una imagen recurrente, no puede ser considerada representativa del programa, pero sí significativa en cuanto a la idea de proyectar un campo que aún mantiene actividades agrarias tradicionales.

En este folleto/cartilla también se observa la construcción de los pueblos turísticos como lugares auténticos, una idea que ya estaba implícita pero que aquí se expone claramente con los mismos apartados utilizados para la región "Campo", pero con el énfasis en esa cualidad que los describe: "Personajes auténticos", "Naturaleza auténtica", "Actividades
Figura 7. Folletos "Pueblos

Turísticos". A. 2010-2011; B. 2012 (general e individual); C. 2013. Ilustraciones y textos de la localidad de Santa María.

Fuente: folletos "Pueblos Turísticos" (2010-2013) 
Figura 8. Ilustración y texto correspondiente a la localidad de Gardey.
Fuente: cartilla "Pueblo Turístico" (2015).

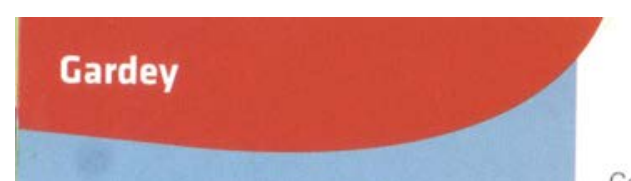

Partido de Tandil

Gardey es una pequeña localidad de casas bajas, ubicada en medio de una horqueta conformada por los arroyos Chapaleofú chico y grande. donde todavia se escuchan historias de los caciques Namuncurá y Catriel. Hoy se nos presenta tranquila y apacible, para ser disfrutada con ritmo de siesta.

\section{Como llegar}

Desde la Ciudad Autónoma de Buenos Aires: Se encuentra ubicado a $385 \mathrm{~km}$. Se puede acceder por Autopista Ricchieri, luego Autopista Ezeiza Cañuelas. Desde alli RN N ${ }^{\circ} 3$ hasta Azul y RP NN 226 con destino a Tandil hasta Km 185, a la derecha $10 \mathrm{~km}$ por el acceso a la Localidad. Desde Tandil:

Se encuentra ubicado a $23 \mathrm{~km}$. Tomar por RP $\mathrm{N}^{\circ}$ 226 con destino a la Ciudad de Azul hasta Km. 185 , a la izquierda $10 \mathrm{~km}$. por el acceso a la localidad.

\section{Contacto}

Dirección de Turismo de Tandil

Avenida. Espora 1120. Tandil

Tel: (0249) 443-2073

turismo@tandil.gov.ar

www.tandil.gov.ar

auténticas", "Patrimonio auténtico", "Gastronomía auténtica" y "Producciones regionales auténticas" (Folletería del programa Pueblos Turísticos, 2015). En cada una de ellas se presenta una foto que ocupa toda la página con un título $(14,5 \times 14 \mathrm{~cm})$, el logo del programa Pueblos Turísticos e información acerca de la foto (a modo de epígrafe). Ello va acompañado de retratos de lugares y personas. Las personas son retratadas con cierta estética diferenciada: en la Figura 9A pueden verse un "gaucho" y una vecina, más solemne el primero y más espontánea la segunda, respecto de quienes se agrega nombre de pila, ocupación y procedencia, como buscando familiaridad. En este caso, la imagen fotográfica contribuye a afianzar la idea de autenticidad.

Asimismo, se reitera la información sobre los lineamientos y propósitos del programa comunitario. De hecho, el texto aquí cambia respecto de las versiones anteriores: está en primera persona del plural, como si fueran los habitantes de los pueblos turísticos quienes se expresan: "Los habitantes de los Pueblos Turísticos ofrecemos a los visitantes experiencias auténticas, basadas en nuestro patrimonio, nuestra naturaleza, gastronomía, producciones regionales, actividades y nuestra propia historia" (Folletería del programa Pueblos Turísticos, 2015). Ello va a acompañado de la primera foto, que muestra a las comunidades locales en reunión (Figura 9B). Se observa que se reiteran los mismos elementos que en los folletos "Tierra de Gauchos" y "Campo" aparecían como títulos. La ruralidad turística de la provincia se construye entonces a partir de esas características, lo que refuerza en el programa el protagonismo de las comunidades locales como "anfitrionas". A su vez, en esta cartilla también se hace más explícita la relevancia del patrimonio como recurso turístico en la promoción. Estos nuevos elementos legitiman al programa como un "producto auténtico" (Figura 9C). 

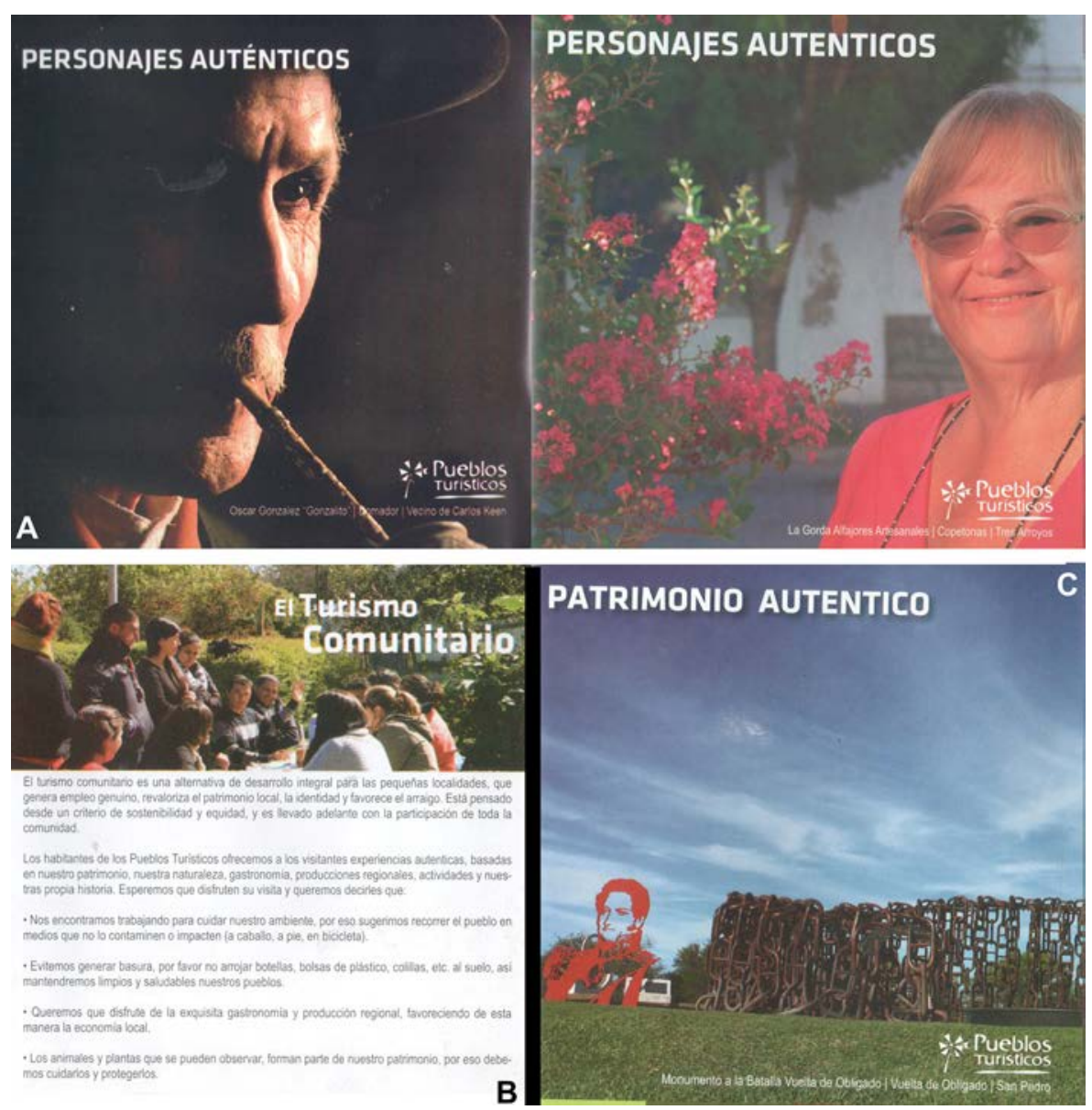

La cartilla dedica una página a cada pueblo. En La Paz (que no aparece en los folletos precedentes) se enlazan de manera especial la idea del pueblo rural como refugio de un pasado casi intacto con los anhelos que genera el turismo. En ella se afirma que:

A lo largo del camino rural que une los parajes de La Paz y La Paz Chica, se encuentra, casi en estado puro, [...] pulperías donde aún pasan sus horas de esparcimiento los habitantes de la región. Cada uno de ellos tiene una historia, una tradición y una familia que encuentra en el turismo la forma de volver a dar vuelo a sus sueños (Folletería del programa Pueblos Turísticos, 2015).

Estas frases refuerzan la idea de autenticidad vinculada a describir a los pueblos como en un "estado puro", de inmutabilidad; a la vez que positiviza al turismo como revitalizador y proveedor de "sueños".

Por otra parte, la incorporación de otros pueblos permite mostrar nuevos destinos que diversifican el conjunto original en términos de atractivos. Por ejemplo, Pardo (ausente en los folletos anteriores) se singulariza por su vínculo con el escritor Adolfo Bioy Casares (1914-1999), nativo del lugar. A la vez que se destaca al pueblo por orientar "la revalorización de técnicas para la construcción natural y la agricultura agroecológica" (Folletería del programa Pueblos Turísticos, 2015), y muestra elementos alternativos e innovadores sobre "lo rural" (en construcción, en agricultura) que lo diferencian claramente del conjunto original de los pueblos turísticos caracterizados por la tradición, la autenticidad y la remisión al pasado. Asimismo, con la inclusión de Gardey, por primera vez se hace mención a los pueblos originarios: "donde todavía se escuchan historias de los caciques Namuncurá y Catriel” (Folletería del programa Pueblos Turísticos, 2015).
Figura 9. A. Imágenes fotográficas que responden a retratos de personajes “auténticos". B. Sección Turismo comunitario. $C$. Sección Patrimonio "auténtico". Fuente: cartilla "Pueblos Turísticos" (2015). 
Sin embargo, en este caso, la fotografía no ilustra la información que se provee de este lugar, sino que complementa, remitiendo a otra: la reactivación del paso del tren con fines turísticos (Figura 8).

Asimismo, se siguen mencionando los primeros pueblos incluidos en el programa, pero en esta cartilla parecerían evidenciar el éxito y la continuidad de la iniciativa. Así, Carlos Keen presenta un párrafo nuevo, en el que se describen los usos actuales a los que se destina la estación: una feria de artesanos y un centro cultural. Y la foto que se utiliza en esta cartilla (no utilizada antes) muestra una gran concurrencia en el predio mencionado (que habitualmente se colma de visitantes cada fin de semana) lo que da cuenta de un destino ya consolidado (Figura 10).

En la cartilla de 2015, la estrategia de organizar y presentar la información sobre los pueblos turísticos en torno a la idea de autenticidad es novedosa en relación con los materiales de promoción elaborados con anterioridad sobre este programa. Así, todo elemento y sujeto participante de este son auténticos. Además, se recurre a la utilización de la primera persona plural para elaborar el texto (lo que da la ilusión de otorgar lugar a la voz de las comunidades), que se identifican en retratos con nombres propios. Esto no solo construye lugares y poblaciones desde una mirada turística (como atractivos), sino que además colabora en la legitimación del programa como instrumento orientado a alcanzar el desarrollo local.

Figura 10. Ilustración y texto correspondiente a la localidad de Carlos Keen. Fuente: cartilla Pueblos Turísti$\cos$ (2015).

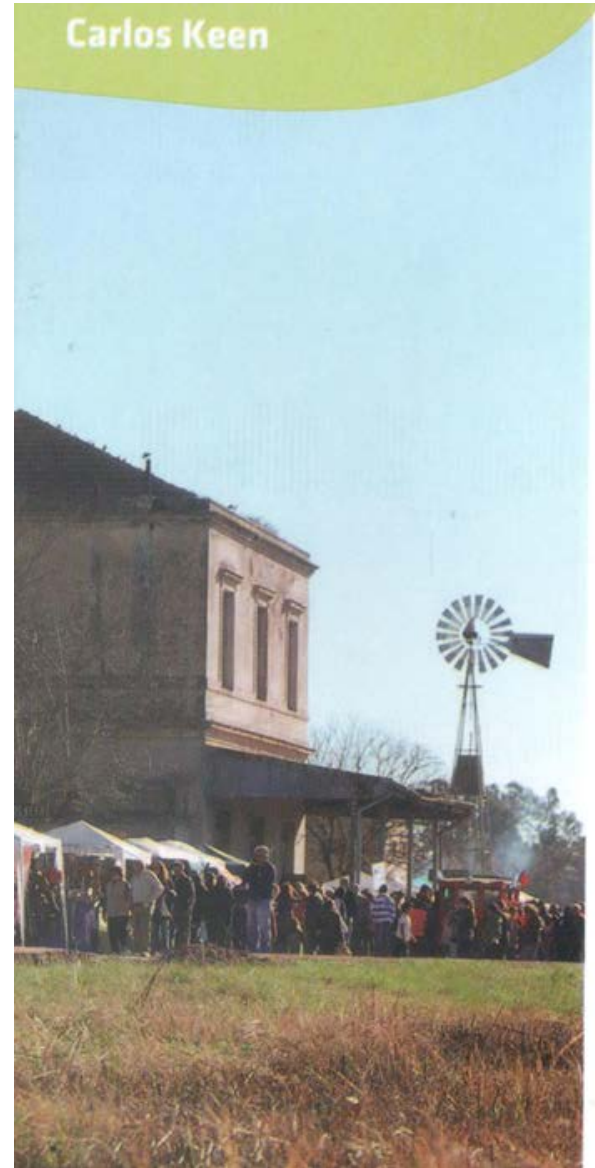

Partido de Luján

Carlos Keen conserva sus caracteristicas originales, del 1800, dándole el mágico aspecto de estar detenido en el tiempo. En esta pequeña localidad de 400 habitantes, se destaca su variada oferta gastronómica, donde es posible disfrutar de los más exquisitos platos criollos. En el predio de la estación se encuentra la feria de artesanos y "El Granero", donde funciona un centro cultural y oficina de informes turisticos, que todas las semanas renueva sus propuestas y actividades para recibir a los visitantes.

\section{Como llegar}

Desde la Ciudad Autónoma de Buenos Aires: Se encuentra ubicado a $83 \mathrm{~km}$. Se puede llegar por el Acceso Oeste y luego RN N ${ }^{\circ} 7$ hasta el km. 72 , donde se debe tomar el camino conocido como "Acceso a Carlos Keen", por el cual hay que transitar $10 \mathrm{~km}$. Este camino se encuentra asfaltado y en buenas condiciones de transitabilidad.

\section{Lentact}

Oficina de Informes Turísticos

Granero de la Estación de Ferrocarril Tel.: (02323) 49-5075

pueblosturisticos@lujan.gov.ar

Dirección de Turismo del Partido de Luján Edificio La Cúpula, San Martín No 1. Luján Tel.: (02323) 42-7082 


\section{La imagen turística de la ruralidad en las pampas bonaerenses}

El trabajo procuró abordar cómo desde la promoción turística oficial, y en particular desde las imágenes que componen los folletos distribuidos a los turistas, se presenta el campo bonaerense en tanto destino turístico. El análisis de estos materiales permitió identificar qué selecciones se llevan adelante desde un actor específico (el estado provincial) que, teniendo en cuenta demandas e intereses turísticos actuales, busca mostrar estos ámbitos geográficos y presentarlos como lugares a los que vale la pena visitar.

En este proceso de construcción de una ruralidad turística bonaerense predomina la utilización y reproducción de ciertos "clichés" y representaciones estereotipadas sobre sujetos y prácticas que se presentan visual y textualmente, lo cual colabora con la difusión y legitimación de determinados "mitos" (Barthes, 1999; Dann, 2001; Hall, 2003). Entre ellos podemos mencionar los mitos de: (i) el gaucho y el paisaje pampeano como sinónimo de libertad, seguridad, especialmente desde la región turística Campo; (ii) la Argentina "blanca y europea", mediante una comunidad producto de las migraciones que tuvo el país durante fines del siglo xix. Es decir, las prácticas agrarias históricas y modernas que movilizan la economía (nacional-global), y que en su momento le dieron el nombre de "granero del mundo" a la Argentina, muestran un país que se forjó gracias al trabajo de los inmigrantes; (iii) las estancias como espacios "civilizados", que al mostrar una idea de continuidad entre el pasado que activan y el presente, generan, como señala Smith (2006), un sentido de validación de esos espacios productivos como íconos nacionalizados, lo cual refuerza y legitima las diferencias de clase. Cabe señalar que estos lugares continúan siendo procurados y consumidos por turistas de alto poder adquisitivo; (iv) una comunidad, además, homogénea, solidaria, unida, sin conflictos ni carencias; (v) el interior rural como refugio de saberes y prácticas tradicionales auténticos, especialmente al destacar la figura del gaucho y sus habilidades; (v) los ámbitos rurales como seguros, tranquilos y hospitalarios y que promueven el estar en "contacto con la naturaleza".

Estos "mitos" son acompañados por un conjunto de aspectos también largamente asociados al campo bonaerense: alimentos y preparaciones considerados típicos; prácticas sociales (recreativas y religiosas) como las celebraciones locales o los juegos de sortija; saberes locales y artesanías específicas. Estos elementos y el pasado ferroviario constituyen, como sostiene Barthes (1999), el material que le provee al turismo el poder configurar, en este caso, una versión de identidad turística asociada a la "cultura rural" pampeano-bonaerense en la que también se coloca a la provincia de Buenos Aires como elemento representativo de lo nacional. Podríamos afirmar que esta construcción turística de lo rural continúa reivindicando esos idearios ya instalados a nivel nacional de una comunidad civilizada blanca y europea, con dominación masculina. En este marco, los elementos negativos de producción agraria actual del campo pampeano no están presentes en estas imágenes (mucho menos en sus aspectos de producción a gran escala y vinculación con mercados internacionales, con uso de tecnología de punta).

Asimismo, los "clichés" - textuales y visuales—, como señala Dann (2001), permiten garantizar familiaridad entre turista y los sujetos "anfitriones" - tanto los dueños de los establecimientos productivos como los residentes de los pueblos-, y seguridad en dos sentidos. Por una parte, al construir el campo como un ámbito tranquilo, inmutable. Por otra, al garantizar al visitante que se encontrará con lo que espera buscar en esos lugares (calidad, calidez, experiencias auténticas). En este sentido, los pueblos rurales y sus comunidades se colocan como lugares que parecen mantener rasgos asociados a la tradición, como la celebración de festejos populares, la gastronomía (es decir, la preservación del patrimonio en todas sus formas), y que portan valores como la hospitalidad y solidaridad, expresados en las imágenes de los vecinos que parecen estar bien predispuestos a recibir a los turistas. Todo esto es presentado como una experiencia para 
encontrarse con lo auténtico, lo artesanal, el servicio personalizado de las comunidades locales. Estas últimas, además, fueron asesoradas y contenidas dentro de un programa (Pueblos Turísticos) que vela por asegurar formas de "turismo comunitario" que no solo se muestran positivas para estas comunidades (en la medida en que se presentan como alternativas para los pueblos afectados por crisis en actividades diversas), sino atractivas para ciertos turistas. Asimismo, y acompañando las intenciones de la política turística provincial, estas opciones turísticas se encuentran "diseminadas" por todo el interior del territorio bonaerense.

Todo esto está presente en la folletería oficial, donde parece que la fotografía progresivamente toma un rol central. En efecto, inicialmente, su uso aparece como una estrategia para ilustrar el texto, sin embargo, luego se utiliza como un recurso que permite reforzar y consolidar estas ideas de ruralidad turística bonaerense esbozadas aquí. Y esto se realiza a partir de complementar información, singularizar destinos y consolidar ideas sobre su autenticidad.

La revisión de los materiales elaborados con fines de promoción turística y las imágenes que los componen nos permiten reflexionar acerca de qué rol ellos cumplen en las formas de caracterizar, definir y presentar ámbitos geográficos y sociedades específicas. En particular, el trabajo aquí expuesto permite interrogarnos acerca de cuál es el papel de la promoción en los procesos en los que parece perpetuarse una lectura urbana sobre lo rural (asimétrica y subordinada) que muestra las bondades del campo a merced de cubrir las expectativas de los turistas urbanos.

Por último, consideramos que el análisis aquí realizado constituye una base sólida para continuar indagando acerca de este proceso de construcción de una ruralidad turística bonaerense, atendiendo a cómo otros actores, además de los organismos estatales, participan en la conformación de lugares turísticos (tales como el sector privado y los propios turistas mediante el uso de plataformas virtuales y las redes sociales).

\section{Sobre las autoras}

Cecilia Pérez Winter es Investigadora Asistente del CONICET. Instituto de Geografía e Instituto de Ciencias Antropológicas (UBA), Buenos Aires, Argentina.

Claudia Troncoso, es Investigadora Adjunta del CONICET. Docente de grado y posgrado de la UBA. Instituto de Geografía, Universidad de Buenos Aires, Buenos Aires, Argentina. 


\section{Q Referencias bibliográficas}

" Adams, K. (2004). The genesis of touristic imagery. Politics and poetics in the creation of a remote Indonesian island destination. Tourist Studies, 4(2), 115-135.

» Aguilar Criado, E., Merino Baena, D., y Migens Fernández, M. (2003). Cultura, políticas de desarrollo y turismo rural en el ámbito de la globalización. Horizontes Antropológicos, 20, 161-183.

"Anderson, B. (1993). Comunidades imaginadas. Reflexiones sobre el origen y la difusión del nacionalismo. México: Fondo de Cultura Económica.

» Aquino, L. (2016). Picture Ahead: a Kodak e a construção do turista-fotógrafo. San Pablo: Edición del autor.

》 Barthes, R. (1986). Lo obvio y lo obtuso. Barcelona: Paidós.

» Barthes, R. (1999). La guía azul. En Mitologías (pp. 68-70). México DF: Siglo XXI.

» Benseny, G. (2002). El sector privado como actor en la gestión del turismo en el territorio de la provincia de Buenos Aires. En Actas de las V Jornadas Nacionales de InvestigaciónAcción en Turismo y VIII Jornadas de Interacción. Mar del Plata. Recuperado de: http:// nulan.mdp.edu.ar/1733/

" Bertoncello, R. (2002). Turismo y territorio. Otras prácticas, otras miradas. Aportes y Transferencias, 6(2), 29-50.

»Bertoncello, R. (2006). Turismo, territorio y sociedad. El "mapa turístico de la Argentina”. En A. Geraiges de Lemos, M. Arroyo y L. Silveira (Eds.), América Latina: ciudades, campo y turismo (pp. 317-335). Buenos Aires: Consejo Latinoamericano de Ciencias Sociales (CLACSO)-Universidad de San Pablo (USP).

»Bertoncello, R. e luso, R. (2016). Turismo urbano en contexto metropolitano: Tigre como destino turístico en el Área Metropolitana de Buenos Aires (Argentina). Revista Colombiana de Geografía, 26(2), 107-125.

" Bracco, M. (2017). La construcción de una imagen turística para la ciudad de Buenos Aires en las guías de viaje de la primera mitad del siglo XX. Nuevo mundo mundos nuevos. Recuperado de: http://journals.openedition.org/nuevomundo/71602. doi: 10.4000/ nuevomundo.71602

» Britton, S. (1991). Tourism, capital and place: toward a critical geography of tourism. Environment and planning, 9, 451-478. doi: 10.1068/do90451

»Castro, H. y Zusman, P. (2016). Debates y derivas sobre la ruralidad contemporánea. Reflexiones desde el campo pampeano. En J. Blanco y S. Lencioni (Eds.), Lo rural y lo urbano en Argentina y Brasil. Geografías materiales y conceptuales en redefinición (pp. 281-308). Río de Janeiro: Consequência.

"Chalfen, R. (1979). Photography's role in tourism. Some unexplored relationships. Annals of tourism research 6(4), 435-447.

"Crawshaw, C. y Urry, J. (1997). Tourism and the photographic eye. En C. Rojek y J. Urry (Eds.), Touring cultures. Transformation of tourism and theory (pp. 176-209). Londres: Routledge.

»Crouch, D. y Lübbren, N. (Eds.) (2003). Visual culture and tourism. Londres: Berg Publishers. 
»Dann, G. (1996). Tourists' Images of a Destination-An Alternative Analysis. Journal of Travel \& Tourism Marketing, 5(1-2), 41-55. doi: 10.1300/Jo73vo5no1_04

»Dann, G. (2001). The self-admited use of cliché in the language of tourism. Tourism, Culture E Communication, 3, 1-14.

»Del Casino, V. y Hanna, S. (2000). Representations and identities in tourism map spaces. Progress in Human Geography, 32, 23-46. doi: 10.1191/030913200673388638

» Edwards, E. y Hart, J. (2004). Introduction: photographs as objects. En E. Edwards y J. Hart (Eds.), Photographs objects histories. On the materiality of images (pp. 1-15). Londres: Routledge.

» Gravari-Barbas, M. y Graburn, N. (2012). Tourist imaginaries. Via@ - international interdisciplinary review of tourism, 1, 1-5.

» Guastavino, M., Rozenblum, C. y Trímboli, G. (2009). Enfoque institucional del INTA para el desarrollo del turismo rural. En IV Congreso Argentino y Latinoamericano de Antropología Rural. Mar del Plata.

» Hall, S. (2003). Representation. Londres: Sage.

»Hiernaux, D. (2002). Turismo e imaginarios. En D. Hiernaux-Nicolás, A. Cordero y L. van Duynen Montijn (Eds.), Imaginarios sociales y turismo sostenible (pp. 7-36). Costa Rica: Facultad Latinoamericana de Ciencias Sociales (FLACSO).

»Hiernaux, D. (2006). Geografía del turismo. En D. Hiernaux y A. Lindon (Coords.), Tratado de geografía humana (pp. 401-432). Barcelona: Anthropos.

» Hughes, G. (1992). Tourism and the geographical imagination. Leisure Studies 11(1), 31-42. doi: 10.1080/02614369100390291

» Knafou, R. (1991). L'invention du lieu touristique: la passation d'un contrat et le surgissement simultané d'un nouveau territoire. Revue de géographie alpine, 79(4), 11-19.

»Larsen, J. (2006). Picturing Bornholm: Producing and Consuming a Tourist Place through Picturing Practices. Scandinavian Journal of Hospitality and Tourism, 6(2), 75-94.

»Lois, C. y C. Troncoso (2017). 10 x 15. Las tarjetas postales como huellas de las prácticas de los turistas. Pasos, 15(3), 633-657.

» MacCannell, D. (1976). The tourist. A new theory of the leisure class. Nueva York: Schocken Books.

» McCabe, S. (Ed.) (2014). Introduction. En The Routledge Handbook of Tourism Marketing (pp. 1-12). Oxon: Routledge.

» Mantero, J. (2001). Regionalización de la gestión turística de la provincia de Buenos Aires. Aportes y Transferencias, 5(1), 67-94.

» Markwick, M. (2001). Postcards from Malta. Image, Consumption, Context. Annals of Tourism Research, 28(2), 417-438. doi: 10.1016/s0160-7383(00)0oo49-9

» Mongan, J., Lombardi, M. y Salim, L. (2012). El sector turismo en la provincia de Buenos Aires. Documento de Trabajo DPEPE NO2/2012. Ministerio de Economía. La Plata, Argentina, Dirección Provincial de Estudios y Proyecciones Económicas. Recuperado de http://www.ec.gba.gov.ar/areas/estudios_proyecciones/documentos/El\%20sector\%20 turismo\%20en\%2ola\%2oprovincia\%2ode\%2oBuenos\%2oAires.pdf

» Morgan, N. y Pritchard, A. (1998). Tourism promotion and power. Creating images, creating identities. West Sussex: John Wiley and Sons.

» Palmer, C. (2009). Research Notes. Moving with the Times: Visual representations of the tourism phenomenon. Journal of Tourism Consumption and Practice, 1(1), 74-85. 
"Pastoriza, E. (2011). La conquista de las vacaciones. Breve historia del turismo en Argentina. Buenos Aires: Edhasa.

»Pereiro, X. y Fernandes, F. (2018). Antropologia e Turismo: Teorias, métodos e práxis. Tenerife: PASOS Edita.

»Pérez Winter, C. (2014). La provincia de Buenos aires (Argentina): de un espacio a un territorio turístico. Turismo visão e ação, 16(3), 544-572.

»Pérez Winter, C. (2015). Encuentros y desencuentros en el desarrollo turístico de la provincia de Buenos Aires (Argentina). Cuadernos de Turismo, 35, 359-377. doi: 10.6018/turismo.35.221651

»Pérez Winter, C. (2016). San Antonio de Areco: la incidencia de la tradición "surera" en los procesos de patrimonialización y turistificación. En M. Rotman (Ed.), Dinámicas de poder. Procesos patrimoniales, políticas y gestión de la cultura (pp. 181-210). Colección Saberes. Buenos Aires: Editorial de la Facultad de Filosofía y Letras UBA.

»Pérez Winter, C. (2017). Ruralidad y turismo en dos "pueblos" de la provincia de Buenos Aires. En N. Finelli y M. Cardoso (Eds.), Temas de investigación y debate en la Ciencia Geográfica (pp. 259-273). Santa Fe: Universidad Nacional del Litoral.

»Quesada, J. y Cadelli, E. (2012). Hacia una caracterización de los municipios bonaerenses. Ministerio de Economía. La Plata, Argentina, Dirección Provincial de Estudios y Proyecciones Económicas. Recuperado de: http://www.ec.gba.gov.ar/areas/estudios_proyecciones/documentos/Hacia\%2ouna\%2oclasificaci\%C3\%B3n\%2ode\%2olos\%2omunicipios\%2obonaerenses.pdf

» Ratier, H., Ringuelet, R. y Soncini, J. (2013). El Mundo Rural: Debates en torno a los nuevos procesos de configuración y reconfiguración en el siglo XXI. Santa Rosa: Universidad Nacional de La Pampa.

» Rose, G. (2002). Visual Methodologies. An Introduction to the Interpretation of Visual Materials. Londres: Sage.

» Rotman, M. B. (2009-2010). El campo patrimonial: procesos de configuración y problematización de alteridades. Memória em Rede, 1(1), 22-42.

"Salazar, N. y Graburn, N. (Eds.) (2014). Introduction. Toward an Anthropology of Tourism Imaginaries. En Tourism imaginaries. Anthropological Approaches (pp. 1-28). Oxford: Berghahn.

»Santillán, V. (2010). La fotografía como creadora de la imagen de un destino turístico. Buenos Aires a través de sus tarjetas postales. Pasos, 8(1): 71-82.

"Scarles, C. (2004). Mediating landscapes: the practices and processes of image construction in tourist brochures of Scotland. Tourist Studies, 4(1), 43-67. doi: $10.1177 / 1468797604053078$

»Schlüter, R. (2003). El turismo en Argentina. Del balneario al campo. Buenos Aires: CIET Centro de Investigaciones y Estudios Turísticos.

» Selwyn T. (Ed.) (1996). The Tourist Image, Myths and Myth Making in Tourism. Wiley: Chichester.

» Smith, L. (2006). The “manored” past: The banality of grandiloquence. En Uses of Heritage (pp. 115-161). Londres: Routledge.

» Smith, V. (1989). Hosts and Guests. The Anthropology of Tourism. Pennsylvania: University of Pennsylvania Press.

» Urry, J. (1990). The tourist Gaze. Londres: Sage. 
»Velázquez Inoue, F. (2018). La valorización turística del campo. En H. Castro y M. Arzeno (Eds.), Lo rural en redefinición. Aproximaciones y estrategias desde la Geografía (pp. 253280). Buenos Aires: Biblos.

"Williams, S. y Lew. A. (2015). Tourism Geographies. Critical understandings of place, space and experience. Londres y Nueva York: Routledge.

"Wilson, J. (Ed.) (2011). The Routledge handbook of tourism geographies. Londres y Nueva York: Routledge.

\section{Otras fuentes consultadas}

»Folletería del programa Pueblos Turísticos (2010-2015). Secretaría de Turismo. Gobiernos de la Provincia de Buenos Aires, La Plata.

" Ley $N^{\circ}$ 13.251, La Plata, Argentina, 30 de septiembre de 2004. Disponible en: http://www.gob.gba.gov.ar/intranet/digesto/PDF/l13251.pdf

» Decreto $N^{\circ}$ 3.977, La Plata, Argentina, 30 de diciembre de 2008. Disponible en: http://www.gob.gba.gov.ar/legislacion/legislacion/o8-3977.html

"Ley $\mathrm{N}^{\circ}$ 14.209, La Plata, Argentina, 22 de diciembre de 2010. Disponible en: http://www.gob.gba.gov.ar/intranet/digesto/PDF/ley14209.pdf

》 LeyN ${ }^{\circ}$ 25.997, Ley Nacional de Turismo, Ciudad de Buenos Aires, 5 de enero de 2005. Disponible en: http://servicios.infoleg.gob.ar/infolegInternet/anexos/1000oo-104999/102724/ norma.htm

" Decreto provincial $N^{\circ}$ 13, La Plata, 3 de enero de 2014. Disponible en: http://www. mp.gba.gov.ar/turismo/downloads/Decreto_13_de_2014.pdf

" Ministerio de Turismo (2015). Anuario Estadístico de Turismo de la Nación. Buenos Aires: Ministerio de Turismo de la Nación. https://www.yvera.tur.ar/estadistica/info/ anuarios-estadisticos-turisticos

» Provincia de Buenos Aires (2011). Plan de regionalización. La estrategia de desarrollo para la provincia. La Plata: Gobierno de la Provincia de Buenos Aires.

»Secretaría de Turismo (2008). “Una apuesta al desarrollo turístico de pequeñas localidades”. Dirección Provincial Turismo Social y Comunitario. Programa de Turismo Comunitario. Recuperado de: http://repotur.yvera.gob.ar/bitstream/handle/123456789/3882/ PROGRAMA_pueblos_turisticos.pdf?sequence $=1 \&$ isAllowed $=y$ 